\title{
EFFECT OF THE BRAZILIAN PROCESS OF THERMAL MODIFICATION ON THE PHYSICAL PROPERTIES OF Eucalyptus grandis JUVENILE WOOD
}

\author{
Djeison Cesar Batista ${ }^{1, \star}$, José Tarcísio da Silva Oliveira ${ }^{2}$, Juarez Benigno Paes ${ }^{2}$, Silvana Nisgoski ${ }^{3}$ \\ Graciela Ines Bolzón de Muñiz
}

\begin{abstract}
This study is a continuation of a previous study published in this journal, with the aim of evaluating the effect of the Brazilian industrial thermal modification process on some physical properties of Eucalyptus grandis juvenile wood. Flatsawn boards of juvenile wood were tested for four treatment levels: untreated and thermally modified wood at final cycle temperatures of $140^{\circ} \mathrm{C}, 160^{\circ} \mathrm{C}$ and $180^{\circ} \mathrm{C}$. Physical properties were assessed according to a standard of the Comisión Panamericana de Normas Técnicas and a method proposed by the specialized literature encompassing equilibrium moisture content (a measure of wood's hygroscopicity), density (oven-dried and air-dried) and radial, tangential and volumetric swelling (from oven-dried to green moisture content). Thermally modified Eucalyptus grandis wood became less hygroscopic, more dimensionally stable (tangential and volumetric swelling) and less dense, even at the lowest temperature tested $\left(140^{\circ} \mathrm{C}\right)$, except for radial swelling, which did not differ from untreated wood.
\end{abstract}

Keywords: Density, equilibrium moisture content, heat treatment, hygroscopicity, swelling.

\section{INTRODUCTION}

Thermal modification significantly affects the properties of wood. Considering just physical properties, thermally modified wood is less hygroscopic and consequently more dimensionally stable. On the other hand, density also declines due to cell wall mass loss, leading to a reduction of mechanical resistance (Esteves and Pereira 2009, Hill 2006, Xie et al. 2002).

Considering this, thermal modification processes must be developed and assessed to achieve a balance between the pros and cons imparted to wood properties, considering the end use. This makes it possible to reach the best process variables (time, temperature and treatment atmosphere, for example) for a specific raw material (species, mature or juvenile wood, heartwood or sapwood, hardwood or softwood), aiming at a specific end use (indoor or outdoor).

In Brazil, Eucalyptus grandis is the most studied species regarding thermal modification because of its large planted area, meaning plentiful availability to supply the wood industry. For this species, some physical properties, such as density, hygroscopicity and dimensional stability are the most studied (Batista and Klitzke 2010, Batista et al. 2011, Cademartori et al. 2012, Cademartori et al. 2015,

\footnotetext{
${ }^{1}$ Professor in the Department of Forest and Wood Sciences, Espírito Santo Federal University, Jerônimo Monteiro, Espírito Santo, Brazil.

${ }^{2}$ Professors in the Department of Forest and Wood Sciences, Espírito Santo Federal University, Jerônimo Monteiro, Espírito Santo, Brazil.

${ }^{3}$ Professors in the Department of Forest Engineering and Technology, Paraná Federal University, Curitiba, Paraná, Brazil. •Corresponding author: djeison.batista@ufes.br

Received: 13.02.2017 Accepted: 16.07.2018
} 
Calonego et al. 2012, Calonego et al. 2014, Garcia et al. 2012, Modes et al. 2013).

These physical properties are among the most studied because represent simple and cheap analysis. Density, for example, is a good parameter for classifying wood quality once it is associated with dimensional stability, mechanical resistance and other wood properties (Stamm 1964). But other properties of thermally modified Eucalyptus grandis wood have also been studied, such as colorimetric variables (Cademartori et al. 2013, Garcia et al. 2014, Lazarotto et al. 2016, Zanuncio et al. 2014a, Zanuncio et al. 2014b) and decay resistance (Calonego et al. 2013, Calonego et al. 2010, Lazarotto et al. 2016), for example.

This study is a continuation of Batista et al. (2016), with the aim of evaluating the effect of the Brazilian industrial process of thermal modification on some physical properties of Eucalyptus grandis juvenile wood.

\section{MATERIAL AND METHODS}

\section{Wood collection, sampling and thermal modification}

The Eucalyptus grandis W. Hill wood used in this study was from an 18-year-old stand (from seeds) planted in the municipality of Telêmaco Borba, Paraná state, southern Brazil. Five trees were felled, but for this study, we sampled only the " $A$ " boards (juvenile flatsawn heartwood), cut from the first three logs (3300 mm length) of each tree (Figure 1). The rest of the wood was also broken down and used to load the thermal modification equipment and for other studies.

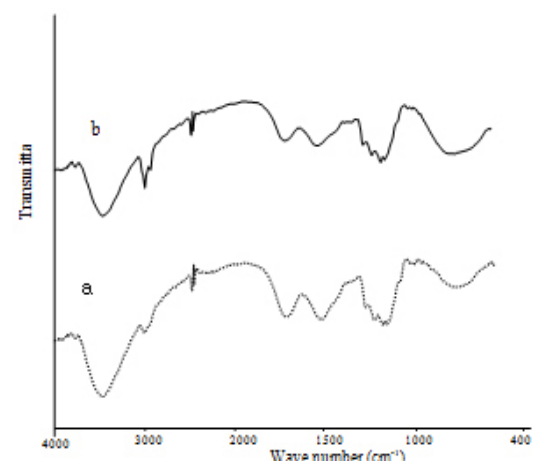

Figure 1. Scheme of the transversal section of a log showing the sampled "A" boards.

The fifteen sampled boards were then trimmed into four parts with equal length $(820 \mathrm{~mm})$ and equally distributed among the four treatment levels investigated: untreated wood and thermally modified wood at final cycle temperatures of $140{ }^{\circ} \mathrm{C}, 160^{\circ} \mathrm{C}$ and $180^{\circ} \mathrm{C}$. These temperatures are the ones commonly used by the company where the research was carried out. The products are intended for indoor use.

Prior to thermal modification, the wood was seasoned until 15\% final moisture content, after which it was thermally modified according to the Brazilian process of thermal modification, in an industrial scale device (steel cylinder with $6 \mathrm{~m}^{3}$ capacity), where one batch was processed separately for each final cycle temperature. Steam generated in a boiler was injected into the cylinder as the heat-transfer medium, which also limits oxidative processes, classifying the process as hygrothermal (Hill 2006). The process is typically divided into five phases, each lasting approximately eight hours, with eight more hours of cooling. The exact schedule is proprietary information, but a more detailed description of the process can be found in Batista et al. (2015). 


\section{Physical properties}

Dimensional stability was assessed according to the swelling test (from the oven-dried to green moisture content) prescribed by standard 462 of the Comisión Panamericana de Normas Técnicas (Copant 1972) adapted by Batista et al. (2011). The specimens were taken from the middle position of the width of the trimmed " $A$ " boards (Figure 1), properly oriented and defect free, with the size of 25 x $25 \times 100 \mathrm{~mm}$ (radial, tangential and longitudinal). We tested 30 specimens for each treatment, two per trimmed "A" board. The same specimens were used in the assessment of the apparent densities (oven-dried and climatic chamber) and equilibrium moisture content (EMC). The latter was used as a measure of hygroscopicity.

The specimens were initially weighed on a digital semi-analytical scale $(0,01 \mathrm{~g})$, oven-dried (103 $\pm 2{ }^{\circ} \mathrm{C}$ ) to constant mass (around 24 hours) and measured with a digital caliper $(0,01 \mathrm{~mm})$ in the longitudinal direction and with a digital micrometer $(0,001 \mathrm{~mm})$ in radial and tangential directions. After that, they were conditioned in a climatic chamber $\left(35 \pm 2{ }^{\circ} \mathrm{C}\right.$ and $65 \pm 3 \% ; 11,5 \%$ EMC) to constant mass (around 15 days), weighed and measured again. Finally, the specimens were immersed in distilled water until complete saturation (constant mass, around seven days), weighed and measured again.

Swelling (radial, tangential and volumetric), apparent densities (oven-dried and climatic chamber) and EMC were calculated according to Equation 1, Equation 2, Equation 3 and Equation 4.

$$
\begin{array}{r}
\alpha_{(t, r, v)}=\frac{\left(D_{g r e e n}-D_{0 \%}\right)}{D_{0 \%}} \times 100 \\
\rho_{0 \%}=\frac{M_{0 \%}}{V_{0 \%}} \\
\rho_{c c}=\frac{M_{c c}}{V_{c c}} \\
E M C=\frac{\left(M_{c c}-M_{0 \%}\right)}{M_{0 \%}} \times 100
\end{array}
$$

Where $-\alpha_{(\mathrm{tr}, \mathrm{v})}$ : tangential, radial or volumetric swelling (\%); $\mathrm{D}_{\text {green }}$ : corresponding green dimension $(\mathrm{mm}) ; \mathrm{D}_{0 \%}$ : corresponding oven-dried dimension or volume $(\mathrm{mm}) ; \rho_{0 \%}$ :oven-dried density $\left(\mathrm{g} / \mathrm{cm}^{3}\right)$; $\mathrm{M}_{0 \%}$ : oven-dried mass $(\mathrm{g}) ; \mathrm{V}_{0 \%}$ : oven-dried volume $\left(\mathrm{cm}^{3}\right) ; \rho_{\mathrm{cc} \%}$ : climatic chamber density $\left(\mathrm{g} / \mathrm{cm}^{3}\right) ; \mathrm{M}_{\mathrm{cc}}$ : equilibrium mass in the climatic chamber $(\mathrm{g}) ; \mathrm{V}_{\mathrm{cc}}$ : equilibrium volume in the climatic chamber $\left(\mathrm{cm}^{3}\right)$; EMC: equilibrium moisture content (\%).

\section{Statistical analysis}

Statistical analysis was performed according to a completely randomized design, with $95 \%$ confidence level. The effect of the treatments was checked by applying the analysis of variance (ANOVA), with Bartlett's test used for validation, which verifies a basic premise for the applying ANOVA, the homogeneity of variances among treatments (Ribeiro-Júnior 2001). In cases of homogeneous variances, ANOVA was applied, while in cases of statistically significant difference between means, Tukey's multiple range test was used to determine which means were different.

If at least one of the variances was not statistically equal, the Kruskal-Wallis H-test was applied, which is a nonparametric method for ANOVA, for classification of an acceptance criteria or experiments with one factor (Spiegel 1994). In this test, the original data of all treatments are increasingly ordered and receive scores, giving a mean score per treatment instead of an overall mean. When at least one mean score was not statistically equal $(\mathrm{p}$-value $<0,05)$ a box-and-whisker plot was used to identify which were different. 


\section{RESULTS AND DISCUSSION}

\section{Equilibrium moisture content (EMC)}

The means of EMC of the four groups (untreated and thermally modified at $140{ }^{\circ} \mathrm{C}, 160^{\circ} \mathrm{C}$ and 180 $\left.{ }^{\circ} \mathrm{C}\right)$ were $8,8 \% ; 7,6 \% ; 5,7 \%$ and $5,2 \%$ respectively. According to Bartlett's test $\left(1,55^{*}\right)$ the variances of the treatments were not homogeneous with $95 \%$ confidence level and the use of ANOVA was unmanageable. Therefore, we applied the $\mathrm{H}$-test $\left(108,49^{*}\right)$, which indicated a significant difference between the mean scores of the treatments with $95 \%$ confidence.

According to Figure 2, there was no overlap of the areas of the notches of any box for the EMC, which means that all the mean scores of the treatments were statistically different with $95 \%$ confidence.

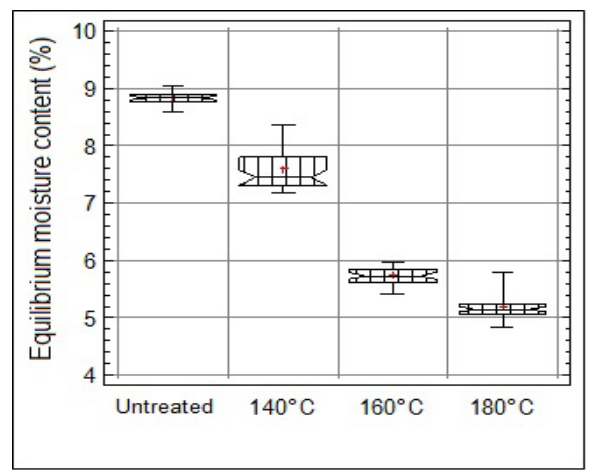

Figure 2. Comparison of mean EMC scores.

EMC of thermally modified wood was significantly lower than untreated wood by $14 \%, 35 \%$ and $41 \%$, respectively, for treatments at $140{ }^{\circ} \mathrm{C}, 160{ }^{\circ} \mathrm{C}$ and $180{ }^{\circ} \mathrm{C}$, so the highest reduction happened between $140{ }^{\circ} \mathrm{C}$ and $160^{\circ} \mathrm{C} \mathrm{(21} \mathrm{percentage} \mathrm{points).} \mathrm{In} \mathrm{this} \mathrm{work,} \mathrm{EMC} \mathrm{was} \mathrm{measured} \mathrm{as} \mathrm{an} \mathrm{indicator}$ of hygroscopicity.

Although the Brazilian process is very different from the European ones, mostly because of the use of different species and the lower temperatures, it is worthwhile making some comparisons. The reductions in hygroscopicity achieved by the treatments at $160{ }^{\circ} \mathrm{C}$ and $180{ }^{\circ} \mathrm{C}$ were higher than those for Plato ${ }^{\circledR}(25 \%)$, but smaller than those for ThermoWood ${ }^{\circledR}(50 \%)$ and Perdure ${ }^{\circledR}(62,8 \%$ to $64,4 \%)$ (Finnish Thermowood Association 2003, Perdure 2011, Platowood 2011). These comparisons show the potential of the Brazilian thermal modification process, mostly because the effect was positive for all the assessed temperatures.

Unfortunately, there are no other studies about Eucalyptus grandis thermally modified wood in an industrial scale process, but it is still informative to compare the results to other studies carried out in laboratory scale, which used ovens and dry heat for thermal modification. In general, the temperatures applied in these studies are higher, reaching $220^{\circ} \mathrm{C}$ and $240{ }^{\circ} \mathrm{C}$ (Batista and Klitzke 2010, Batista et al. 2011, Cademartori et al. 2015, Calonego et al. 2012, Garcia et al. 2012), because it is easier to control higher temperatures in small devices. Nevertheless, in some of these studies and in the study of Calonego et al. (2014), $180^{\circ} \mathrm{C}$ was also assessed.

Comparing the treatment at $180{ }^{\circ} \mathrm{C}$, higher reductions were achieved in the industrial process (41\%) than in the studies of Calonego et al. (2012) - 21\%, Calonego et al. (2014) - 14\% and Garcia et al. (2012) $-10 \%$. The reduction was higher than that achieved for treatments carried out at higher temperatures $\left(200^{\circ} \mathrm{C}\right)$, as reported by Batista and Klitzke (2010) $-10 \%$. On the other hand, Cademartori et al. (2015) reported 55\% reduction in the EMC for $180^{\circ} \mathrm{C}$ and Batista and Klitzke (2010) reported similar results $(60 \%)$ for $230{ }^{\circ} \mathrm{C}$.

Reduction in hygroscopicity of thermally modified wood is mostly related to the loss of 
hemicelluloses, as well as the production of a high content of extractives, which also contributes to reduced hygroscopicity (Esteves and Pereira 2009, Hill 2006, Stamm 1964, Xie et al. 2002).

Figure 3 depicts the behavior of EMC when compared to the chemical composition, according to data published by Batista et al. (2016), who assessed the same material (species, process, and treatments). Batista et al. (2016) found that the temperatures used were not high enough to cause mass loss of cellulose, so the holocellulose reductions resulted from thermal degradation of hemicelluloses.

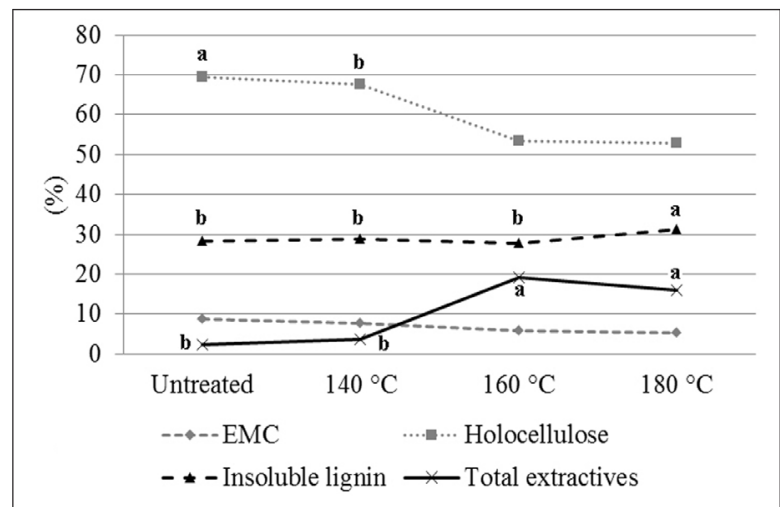

Figure 3. Behavior of EMC and chemical composition of wood (adapted from Batista et al. 2016) the letters in the graph represent the Tukey tests statistics.

EMC of thermally modified wood had the same tendency as holocellulose content, where the smaller the holocellulose content was, the lower the EMC was because carbohydrates are the most hygroscopic cell wall compounds and their mass loss represents a reduction in the sites for water bonding. For extractives content and EMC, the effect was inverse to that for holocellulose and EMC. The extractives content increased significantly, indicating that the mass loss resulted in the production of chemical compounds of low molecular mass, also assessed as extractives content.

Comparing EMC with lignin content, we noted that its effect was not significant for hygroscopicity reduction. According to the literature, lignin is the least hygroscopic compound of the cell wall (Skaar 1972) and is significantly degraded only at temperatures above those tested in this study (Fengel and Wegener 1989). For further discussion of the chemical composition of thermally modified Eucalyptus grandis wood, see the study of Batista et al. (2016).

Based on the chemical results of the treatments at $160{ }^{\circ} \mathrm{C}$ and $180{ }^{\circ} \mathrm{C}$, which had the smallest average EMC values, some considerations can be made: the means of holocellulose did not differ significantly; the average lignin content at $160^{\circ} \mathrm{C}$ was smaller; the mean extractives content at $160{ }^{\circ} \mathrm{C}$ was higher; and the mean EMC at $180^{\circ} \mathrm{C}$ was smaller.

So, isolated analysis of the chemical composition of wood did not permit establishing a clear relationship between cause and effect in EMC as in the overall analysis of the treatments. These results indicate that the real behavior of wood is due to the synergy of its chemical compounds and not to their isolated effects.

It is also necessary to consider that not all the extractives produced by the degradation of holocellulose and lignin have the same nature, so their behavior and role in the cell wall also differ, which can explain the EMC results.

Further, regarding the EMC results, it should be noted that the hysteresis effect is added to the effects previously discussed, according to findings of Batista and Klitzke (2010), who used the same method for EMC determination. 


\section{Density}

Both apparent densities (oven-dried and climatic chamber) had the same behavior. Thermal modification reduced wood density significantly and the higher the temperature, the higher the reduction (Table 1). It is noteworthy that the means of the treatments at $140{ }^{\circ} \mathrm{C}$ and $160{ }^{\circ} \mathrm{C}$ did not differ significantly for both apparent densities.

Treatment at $180{ }^{\circ} \mathrm{C}$ caused the highest reductions in density, with $13 \%$ and $16 \%$ for oven-dried and climatic chamber, respectively. Reduction in density has the same origin as hygroscopicity: mass loss of cell wall compounds, mostly hemicelluloses, and it is a positive effect of thermal modification processes. Conversely, reduction in density results in weaker mechanical resistance. That is why it is important to find a balance between the pros and cons of the process according to a particular end use for the wood product, because the mass loss is dependent on the process, mainly time, temperature, atmosphere condition (gas, pressure) and the raw material.

Table 1. Means of wood density.

\begin{tabular}{|c|c|c|c|c|}
\hline \multirow{2}{*}{ Treatment } & \multicolumn{4}{|c|}{ Density (g/cm $\mathbf{~}^{\mathbf{3}}$} \\
\cline { 2 - 5 } & Oven-dried & Reduction (\%) & $\begin{array}{c}\text { Climatic } \\
\text { chamber }\end{array}$ & Reduction (\%) \\
\hline Untreated & $0,46 \mathrm{a}$ & - & $0,49 \mathrm{a}$ & - \\
\hline $140^{\circ} \mathrm{C}$ & $0,44 \mathrm{~b}$ & 4 & $0,46 \mathrm{~b}$ & 6 \\
\hline $160^{\circ} \mathrm{C}$ & $0,44 \mathrm{~b}$ & 4 & $0,46 \mathrm{~b}$ & 6 \\
\hline $180^{\circ} \mathrm{C}$ & $0,40 \mathrm{c}$ & 13 & $0,41 \mathrm{c}$ & 16 \\
\hline Bartlett's test & $1,05^{\text {ns }}$ & - & $1,06^{\text {ns }}$ & - \\
\hline ANOVA-F test & $15,24^{*}$ & - & $19,19^{*}$ & - \\
\hline
\end{tabular}

Means followed by the same letter in the column do not differ significantly according to Tukey's test ( $95 \%$ confidence level). ns: not significant ( $95 \%$ confidence level). *: significant $(95 \%$ confidence level).

The reductions in density caused by temperature increase are in accordance with what was reported in the literature for the European processes, although the kind of density assessed is not mentioned to provide a proper comparison. Density is reduced up to $12.5 \%$ by the ThermoWood ${ }^{\circledR}$ process, regarding $230{ }^{\circ} \mathrm{C}$ (Finnish Thermowood Association 2003). For Plato ${ }^{\circledR}$, up to $10 \%$ is expected (Platowood 2011), while for Retification ${ }^{\circledR}$, it varies from $4 \%$ to $9 \%$ (Retiwood 2011).

Comparing the results to those of a laboratory scale process for the same species and temperatures $\left(140{ }^{\circ} \mathrm{C}, 160{ }^{\circ} \mathrm{C}\right.$ and $\left.180{ }^{\circ} \mathrm{C}\right)$, smaller reductions were reported by Calonego et al. (2012) for both oven-dried $(2,1 \%$ to $6,7 \%)$ and air-dried $(0,5 \%$ to $4,1 \%)$ densities. In some cases, thermal modification had no effect on the oven-dried density of wood at $180{ }^{\circ} \mathrm{C}$ (Calonego et al. 2014) and even $200{ }^{\circ} \mathrm{C}$ (Batista et al. 2011). Garcia et al. (2012) also reported a smaller reduction in air-dried density $(10 \%)$ at $180{ }^{\circ} \mathrm{C}$. Only Batista et al. (2011) reported a higher reduction in oven-dried density $(20 \%)$ at $230{ }^{\circ} \mathrm{C}$.

These results indicate that the Brazilian industrial process, which uses wet heat, is more aggressive regarding the mass loss of cell wall compounds than the laboratory scale processes, which use dry heat.

\section{Swelling}

Thermal modification reduced the samples' hygroscopicity and density, and since both properties are directly related to swelling (Stamm 1964), we expected the swelling to be reduced as well.

The process of thermal modification (Table 2) significantly reduced the swelling of Eucalyptus grandis wood with increasing temperature, except the radial swelling did not have the same behavior 
because the mean of the treatment at $140{ }^{\circ} \mathrm{C}(3,85 \%)$ did not differ significantly from the untreated $(4,18 \%)$. Also for radial swelling, we found an unexpected result because the mean of the treatment at $180{ }^{\circ} \mathrm{C}$ was higher than that at $160^{\circ} \mathrm{C}$.

Table 2. Averages of swelling (oven-dried to green).

\begin{tabular}{|c|c|c|c|c|}
\hline \multirow{2}{*}{ Treatment } & \multicolumn{3}{|c|}{ Swelling (\%) } & $\begin{array}{c}\text { Volumetric } \\
\text { reduction (\%) }\end{array}$ \\
\cline { 2 - 5 } & Radial & Tangential & Volumetric & - \\
\hline Untreated & $4,18 \mathrm{a}$ & $8,88 \mathrm{a}$ & $13,40 \mathrm{a}$ & 17 \\
\hline $140^{\circ} \mathrm{C}$ & $3,85 \mathrm{a}$ & $7,06 \mathrm{~b}$ & $11,13 \mathrm{~b}$ & 34 \\
\hline $160^{\circ} \mathrm{C}$ & $2,56 \mathrm{c}$ & $5,99 \mathrm{c}$ & $8,82 \mathrm{c}$ & 35 \\
\hline $180^{\circ} \mathrm{C}$ & $3,05 \mathrm{~b}$ & $5,45 \mathrm{~d}$ & $8,77 \mathrm{c}$ & - \\
\hline Bartlett's test & $1,06^{\mathrm{ns}}$ & $1,05^{\mathrm{ns}}$ & $1,06^{\mathrm{ns}}$ & - \\
\hline ANOVA $-\mathrm{F}$ test & $58,74^{*}$ & $234,00^{*}$ & $246,57^{*}$ & \\
\hline
\end{tabular}

Means followed by the same letter in the column do not differ significantly according to Tukey's test (95\% confidence level). ns: not significant ( $95 \%$ confidence level). $*$ : significant (95\% confidence level).

The average volumetric swelling values of the treatments at $160{ }^{\circ} \mathrm{C}$ and $180{ }^{\circ} \mathrm{C}$ did not differ significantly and they achieved the highest reductions (34\% and 35\%). These results are similar to those of Retification ${ }^{\circledR}-25 \%$ to $43 \%$ (Retiwood 2011) but are smaller than those reported for Perdure ${ }^{\circledR}$, Plato $^{\circledR}$ and ThermoWood ${ }^{\circledR}$, with $39 \%$ to $64 \%, 50 \%$ to $67 \%$ and $68 \%$, respectively (Finnish Thermowood Association 2003, Perdure 2011, Platowood 2011).

Comparing the results to those of a laboratory scale process for the same species and temperatures, the Brazilian industrial process was more effective in reducing the volumetric swelling. Calonego et al. (2012) reported reductions of $8,4 \% ; 14,5 \%$ and $23,2 \%$ respectively at $140{ }^{\circ} \mathrm{C}, 160{ }^{\circ} \mathrm{C}$ and $180{ }^{\circ} \mathrm{C}$. For $180^{\circ} \mathrm{C}$, Calonego et al. (2014) reported reductions of $14,7 \%$ and Batista et al. (2011) reported 20\% reduction for treatments at $200{ }^{\circ} \mathrm{C}$.

We calculated the linear correlation coefficient between the data of EMC x volumetric swelling, oven-dried density x volumetric swelling and air-dried density x volumetric swelling. We used Student's t-test to analyze the significance of the correlations. All the correlations were positive and significant at $95 \%$ confidence and the best results were achieved for the correlation between EMC and volumetric swelling $\left(\mathrm{r}=0,917^{*}\right)$, while the correlations between EMC and oven-dried density $\left(0,595^{*}\right)$ and airdried density were weaker $(\mathrm{r}=0,620 *)$.

Improvements in dimensional stability caused by the reduction in hygroscopicity, imparted by thermal modification processes, is desired for lumber mostly in indoor products with high added value. This is perhaps the most noteworthy advantage of thermally modified Eucalyptus grandis juvenile wood, which is otherwise recognized for its poor dimensional stability.

On the other hand, it is necessary to assess the effects of thermal modification on mechanical resistance because of the reductions in density.

\section{CONCLUSIONS}

Thermally modified Eucalyptus grandis juvenile wood became less hygroscopic, more dimensionally stable and less dense, even at the lowest temperature tested $\left(140{ }^{\circ} \mathrm{C}\right)$, except for radial swelling at $140{ }^{\circ} \mathrm{C}$ which did not differ from control. 
Equilibrium moisture content and tangential swelling continuously decreased with increasing temperature from $140{ }^{\circ} \mathrm{C}$ to $180^{\circ} \mathrm{C}$.

Higher reductions in hygroscopicity and density were achieved at the highest temperature tested $\left(180^{\circ} \mathrm{C}\right)$, but for volumetric swelling, there was no difference between the treatments at $160{ }^{\circ} \mathrm{C}$ and $180^{\circ} \mathrm{C}$.

The effect of thermal modification was higher in the reduction (\%) of hygroscopicity and dimensional stability than in the reduction (\%) of the apparent densities.

Reductions in hygroscopicity and density were caused by the mass loss of hemicelluloses and by the increase in the extractives content, produced mainly, but not exclusively, by carbohydrate degradation.

\section{REFERENCES}

Batista, D.C.; Paes, J.B.; Muñiz, G.I.B. de; Nisgoski, S.; Oliveira, J.T. da S. 2015. Microstructural aspects of thermally modified Eucalyptus grandis wood. Maderas-Cienc Tecnol 17(3): 525-532.

Batista, D.C.; Muñiz, G.I.B. de; Oliveira, J.T. da S.; Paes, J.B.; Nisgoski, S. 2016. Effect of the Brazilian thermal modification process in the chemical composition of Eucalyptus grandis juvenile wood - part 1: cell wall polymers and extractives contents. Maderas-Cienc Tecnol 18(2): 273-284.

Batista, D.C.; Tomaselli, I.; Klitzke, R.J. 2011. Efeito do tempo e temperatura de modificação térmica na redução do inchamento máximo da madeira de Eucalyptus grandis Hill ex Maiden. Ciência Florestal 21(3): 533-540.

Batista, D.C.; Klitzke, R.J. 2010. Influência do tempo e temperatura de retificação térmica na umidade de equilíbrio da madeira de Eucalyptus grandis Hill ex Maiden. Scientia Forestalis 38(86):255-261.

Cademartori, P.H.G. de; Schneid, E.; Gatto, D.A.; Beltrame, R.; Stangerlin, D.M. 2012. Modification of static bending strength properties of Eucalyptus grandis heat-treated wood. Materials Research 15(6):922-927.

Cademartori, P.H.G. de; Schneid, E.; Gatto, D.A.; Stangerlin, D.M.; Beltrame, R. 2013. Thermal modification of Eucalyptus grandis wood: variation of colorimetric parameters. MaderasCienc Tecnol 15(1):57-64.

Cademartori, P.H.G. de; Missio, A.L.; Mattos, B.D.; Gatto, D.A. 2015. Effect of thermal treatments on technological properties of wood from two Eucalyptus species. Anais da Academia Brasileira de Ciências 87(1):471-481.

Calonego, F.W.; Severo, E.T.D.; Furtado, E.L. 2010. Decay resistance of thermally-modified Eucalyptus grandis wood at $140{ }^{\circ} \mathrm{C}, 160{ }^{\circ} \mathrm{C}, 180{ }^{\circ} \mathrm{C}, 200{ }^{\circ} \mathrm{C}$ and $220^{\circ} \mathrm{C}$. Bioresource Technology 101 (23):9391-9394.

Calonego, F.W.; Severo, E.T.D.; Ballarin, A.W. 2012. Physical and mechanical properties of thermally modified wood from E. grandis. European Journal of Wood Products 70:453-460.

Calonego, F.W.; Severo, E.T.D.; Brito, A.F. de. 2013. Tipos de ruptura em madeira de Eucalyptus grandis modificada termicamente. Silva Lusitana, Especial:153-161. 
Calonego, F.W.; Severo, E.T.D.; Latorraca, J.V. de F. 2014. Effect of thermal modification on the physical properties of juvenile and mature woods of Eucalyptus grandis. Floresta e Ambiente 21(1):108-113.

Comisión Panamericana de Normas Técnicas. COPANT. 1972. Método de determinación de la contracción. COPANT 462-1972

Esteves, B.M.; Pereira, H.M. 2009. Wood modification by heat treatment: a review. BioResources 1(4): $370-404$.

Fengel, D.; Wegener, G. 1989. Wood: chemistry, ultrastructure, reactions. Walter De Gruyter, New York.

Finnish Thermowood Association. 2003. ThermoWood ${ }^{\mathbb{B}}$ handbook. Finnish Thermowood Association: Helsinki. 66 p.

Garcia, R.A.; Carvalho, A.M. de; Latorraca, J.V. de F.; Matos, J.L.M. de; Santos, W.A.; Silva, R.F. de M. 2012. Nondestructive evaluation of heat-treated Eucalyptus grandis Hill ex Maiden wood using stress wave method. Wood Science and Technology 46:41-52.

Garcia, R.A.; Lopes, J. de O.; Santos, W.A. 2014. Modificação da cor original da madeira de Eucalyptus grandis através de tratamentos termorretificadores. Cerne 20(3):449-457.

Hill, C. 2006. Wood modification: chemical, thermal and other processes. John Wiley \& Sons, West Sussex.

Lazarotto, M.; Cava, S. da S.; Beltrame, R.; Gatto, D.A.; Missio, A.L.; Gomes, L.g.; Mattoso, T.R. 2016. Resistência biológica e colorimetria da madeira termorretificada de duas espécies de eucalipto. Árvore 40(1):135-145.

Modes, K.S.; Santini, E.J.; Vivian, M.A. 2013. Hygroscopity of wood from Eucalyptus grandis and Pinus taeda subjected to thermal treatment. Cerne 19(1):19-25.

Perdure. 2011. Research and development: physical properties. PCI Industries, Quebec.

Platowood. 2011. Platowood infosheet: physical and mechanical properties. Platowood BV, Arnhem. 2 pp.

Retiwood. 2011. Research and development: physical properties. Retiwood, Paris. 1 p.

Ribeiro-Júnior, J. I. 2001. Análises estatísticas no SAEG. Universidade Federal de Viçosa, Viçosa.

Skaar, C. 1972. Water in wood. Syracuse University Press, Syracuse. 218 pp, United States of America.

Spiegel, M.R. 1994. Estatística. 3. ed. Pearson Education do Brasil, São Paulo.

Stamm, A.J. 1964. Wood and cellulose science. The Ronald Press, New York.

Xie, Y.; Liu, Y.; Sun, Y. 2002. Heat treated wood and its development. Journal of Forestry Research, 13(3):224-230.

Zanuncio, A.J.V.; Farias, E. de S.; Silveira, T.A. da. 2014a. Termorretificação e colorimetria da madeira de Eucalyptus grandis. Floresta e Ambiente 21(1):85-90. 
Zanuncio, A.J.V.; Nobre, J.R.C.; Motta, J.P.; Trugilho, P.F. 2014b. Química e colorimetria da madeira de Eucalyptus grandis W.Mill ex Maiden termorretificada. Árvore 38(4):765-770. 